\title{
Subnational Debt Renegotiation and Elections: Experimentation and Reputation in the Brazilian Fiscal Federalism*
}

\author{
Maurício Soares Bugarin ${ }^{* *}$
}

\begin{abstract}
The present paper analyzes the effect of elections on subnational fiscal policy after debt renegotiations between local (state) governments and the Federal government. First, a stylized model determines under which conditions a state will accept the debt renegotiation requirements and highlights an incentive for the state to reduce tax effort after renegotiation. Next, a dynamic model shows that elections bring about new incentives for nonpayment of debt interests to the Federal government. The model's solution yields two perfect Bayesian equilibria. In the first "experimentation equilibrium" new state governors decide to stop payment of debt interests in order to test the Federal government's willingness to get involved in a politically costly confrontation. In the second "reputation equilibrium" the Federal government decides to withhold federal transfers to any defaulting state, in spite of the high political cost of that decision, in order to avoid defaulting by other states in the future.
\end{abstract}

Keywords: Debt Renegotiation, Elections, Fiscal Policy, Experimentation, Reputation.

JEL Codes: C72, D72, H63, H72, H77.

${ }^{*}$ Submitted in November 2004. Revised in February 2006. This paper is an extension of the article by Pires and Bugarin (2002), which, in turn, is based on a chapter by Sotomayor and Bugarin (1998). The author thanks Marilda Sotomayor and Henrique Pires for their partnership in the previously mentioned works, and also thanks Mirta Bugarin, Ivan Ferreira, Gustavo Gonzaga, Eduardo Loyo, Fernando Meneguin, Ajax Moreira, Paulo Tafner, Rogério Werneck and other attendants to IPEA/Rio and PUC/Rio seminars and to the Second World Congress of the Game Theory Society, for their valuable suggestions and comments. The author also acknowledges the financial support received from $\mathrm{CNPq}$ and from Finatec and takes full responsibility for the opinions expressed herein, as well as for any possible errors.

** Departamento de Economia, Universidade de Brasília, ICC Norte, Asa Norte, 60910-900, Brasília, DF. E-mail: bugarin@unb.br 


\section{Introduction}

At her oath of office ceremony in January 2003, Rosinha Garotinho, the new governor of the state of Rio de Janeiro, protested about a debt of 300 million reais her predecessor had neglected to pay to the federal government. According to the new governor, "it was a veiled moratorium. This week, we are going to call [Finance] Minister Antônio Palocci. The Workers' Party is to blame for not paying the debt". ${ }^{1}$ The outcome of this dispute is public knowledge: the new state governor decided to default on federal owned state debt; in response, the Brazilian Treasury Department withheld a federal transfer of 86 million reais to that state; then, the state government appealed to the Supreme Court for the release of federal transfers, and an injunction against the federal government was granted, as the Court presumed that "the provision of basic services could be jeopardized"; however, the injunction was later lifted.

The behavior of the newly sworn-in state governor was not unique in Brazilian politics. Four years earlier, in January 1999, the then new governor of Minas Gerais, Itamar Franco, announced a moratorium, defaulting on the payment of state debts for 90 days, claiming that the state debt was "impossible to pay". ${ }^{2}$ The resulting political stalemate had a similar outcome to that of the state of Rio de Janeiro in 2003: federal transfers to the state were withheld, as established in the debt renegotiation contract signed between the state government of Minas Gerais and the federal government.

The conduct of state governments in these two episodes is not easy to grasp. Indeed, by renegotiating the debt, one expects the state government to be aware that contract clauses established withholding of state funds in case of default. Nevertheless, there seems to be a strong "electoral effect" upon the behavior of state governments, which encourages nonpayment of debt inherited from previous governors.

The aim of the present paper is to analyze the incentives that may prompt a state to voluntarily sign a debt renegotiation contract and then renege on it after the state's elections, in spite of the political and financial risks associated with such one-sided and costly confrontation. Obviously, the analysis performed herein also applies to municipal governments that recently renegotiated their debts with the Brazilian federal government.

The methodology is based on reputation models initially developed in Kreps and Wilson (1982) and in Milgrom and Weber (1982). An application of the basic ideas within the context of industrial organization can be found in Sotomayor and Bugarin (1998). The paper by Pires and Bugarin (2002) is more closely related to the present work, since it touches upon the possibility of one state defaulting on payments due after the debt renegotiation contracts. The main additional contri-

\footnotetext{
${ }^{1}$ Revista Isto é? (1736, January 8, 2003).

2 Revista Veja (1580, January 13, 1999).
} 
butions of the present study are threefold. First, there is a dynamic analysis of the debt accumulation process that helps understanding under which conditions the governor will be willing to accept a rather restrictive debt renegotiation contract. Second, with respect to the reputation model, there are now two different types of state, which allows for incomplete information already in the first period of the corresponding game. This extension suggests a discussion about the experimentation and the precautionary principles in the state's behavior. This paper shows that, when the federal government starts the game with a reputation of being tough, it should withhold transfers to any defaulting state in spite of the political cost that this decision may cause, in order to refrain other states from defaulting. Additionally, this paper studies the situation in which the federal government starts off with a disadvantage in terms of reputation, i.e., a situation in which society regards the federal government as weak, with high probability. The main contribution to the latter issue is that the federal government's toughening stance becomes inappropriate and should be replaced by a mixed strategy in which the government withholds state transfers with a positive probability, but lower than one.

In addition to this introduction, the present study is organized into six sections. Section 2 analyzes the incentives that may lead a state to accept a debt renegotiation contract that prevents it from making new debt (at least for a specific time frame). A stylized model for debt renegotiation emphasizes the role played by the cost of the tax effort, by the size of the debt stock, and by the market sensitivity to state debt, in the decision to renegotiate. It also draws attention to the effect of renegotiation on reducing the state's tax effort.

Section 3 shows how the electoral process may bring about new incentives for the state, focusing on the potential conflict between fulfilling election promises, choosing an optimal tax effort level, and paying debt interests.

Section 4 assesses the behavior of the state and of the federal government after debt renegotiation and after elections in a situation where there is complete information about the elected state governor and the elected president. The main results suggest that at times of political fragility all state governments may decide not to pay their debts, even when they are not facing financial hardship, resulting in the so-called "debt renegotiation paradox".

Section 5 determines equilibria when the state has incomplete information about the type of federal government and the federal government has incomplete information about the state government's type. Three different perfect Bayesian equilibria are identified. The first one, called "experimentation equilibrium", occurs in a single-period game between a state and the federal government, when the state believes that the federal government is politically weak with high probability. In this case, the state will not pay its debts regardless of its type and federal transfers will only be withheld when the federal government is politically strong. The second equilibrium, called "reputation equilibrium", occurs in a two- 
period sequential game between two states and the federal government, when the states believe there is high probability that the federal government is politically strong. In this case, the state will avoid, as much as possible, defaulting on its debt interests payments. However, a state facing financial hardship will declare a moratorium anyway, in which case the federal government will withhold federal transfers, although that behavior may bring extensive political costs to the federal government. Therefore, in a reputation equilibrium, even a politically weak federal government will choose to bear the political costs related to blocking federal transfers to the state, so as to yield a tough reputation and prevent other states from defaulting on their debts in the future. The third equilibrium, called "reputation building equilibrium", occurs in a two-period sequential game between two states and the federal government, when the states believe the federal government is politically strong with small probability. In that case, the federal government can acquire a reputation for being tough by adopting a mixed strategy for withholding federal transfers to a defaulting state with a positive probability, but lower than one.

Finally, section 6 provides some extensions to this basic model, and section 7 concludes.

\section{A Debt Renegotiation Model}

\subsection{Market discipline and tax effort: the state before debt renegotia- tion}

\subsubsection{Description}

Consider a state government that has total autonomy over its level of expenditure before debt renegotiation. In each period $t \geq 0$, the state derives exclusive utility from the total amount spent $\left(G_{t}\right)$, which is financed by means of federal transfers $^{3}(\tau)$, tax revenues raised by the state $\left(T_{t}\right)$ and borrowings $\left(D_{t}\right)$ from the financial system. The level of deficit (borrowings) of the state is controlled by the market alone, which will lend at interest rates $\left(r_{t}\right)$ (the higher the deficit, the higher the interest rates). On the other hand, the amount of tax revenue locally collected by the state will depend on its tax base $\left(T_{0}\right)$ and on its tax effort, which is costly. Function $\psi\left(\mathrm{T}_{t}\right)$ describes the cost of collecting an amount $T_{t}$ of tax revenue.

\footnotetext{
${ }^{3}$ Constitutional transfers such as the State Participation Fund, SPF, and voluntary transfers. Since this is a state variable (as opposed to control variable) from the subnational government standpoint, these transfers are regarded as constant in the present model. Alternatively, one could consider the form $\tau=\tau_{0}+\tau\left(V_{t}\right)$ for federal transfers, where $V_{t}$ is a set of control variables, for instance, $V_{t}=\mathrm{T}_{t}$. In this case, $\tau_{0}$ would correspond to mandatory and unconditional constitutional transfers, whereas $\tau\left(\mathrm{V}_{t}\right)$ would correspond to voluntary transfers that could be conditioned on the tax effort of the state. For simplicity, the present study disregards this additional mechanism the federal government could use to exercise control over the states. The author thanks an anonymous referee for this comment.
} 
Thus, the state's utility function can be described by ${ }^{4} G_{t}-\psi\left(T_{t}\right)$. Total expenditure $G_{t}$ is given by the budget constraint of the state $G_{t}=D_{t}+\tau+T_{t}-r_{t} B_{t}$ where $B_{t}$ stands for the debt stock of the state such that $r_{t} B_{t}$ is the amount of interest the state pays on its debt. The interest rate $r_{t}$ is a convex function of the state deficit, $D_{t}$, and of the relationship between its revenues and its debt stock, $\left(\tau+T_{t}\right) / B_{t}$, strictly increasing in the first variable and strictly decreasing in the second one. For simplicity, this study adopts the following parameterization for the interest rate function.

$$
r_{t}=r\left(D_{t}, \frac{\tau+T_{t}}{B_{t}}\right)=r_{U}+b D_{t}-c \frac{\tau+T_{t}}{B_{t}}
$$

The term $r_{U}$ above corresponds to the interest rate the federal government pays on its debt, and the last two terms on the right are expressions for the additional spread the state government pays. The positive parameters $b$ and $c$ indicate that the spread increases as the deficit increases and that it decreases as state debt sustainability increases.

Function $\psi\left(T_{t}\right)$ measures the cost for the state to collect tax $T_{t}$. It reflects the fact that there exists a political cost associated with tax collection, in addition to an administrative cost for maintaining tax collection and supervision institutions. This function $\psi\left(T_{t}\right)$ is assumed to be strictly increasing and strictly convex, with a vertical asymptote at value $T_{0} \cdot{ }^{5}$ For simplicity, the model adopts the following expression $\psi\left(T_{t}\right)$.

$$
\psi\left(T_{t}\right)=\theta \log \left(\frac{T_{0}}{T_{0}-T_{t}}\right)
$$

Parameter $\theta$ represents the state's ability to raise funds through tax collection: the larger $\theta$ is, the costlier it is for the state to collect amount $T_{t}$. This parameter characterizes the type of state.

Therefore, the state utility in period $t$ is:

$$
\begin{aligned}
U\left(D_{t}, T_{t}\right) & =G\left(D_{t}, T_{t}\right)-\psi\left(T_{t}\right) \\
& =D_{t}+\tau+T_{t}-r\left(D_{t}, \frac{\tau+T_{t}}{B_{t}}\right) B_{t}-\psi\left(T_{t}\right) \\
& =D_{t}+\tau+T_{t}-r_{U} B_{t}-b D_{t} B_{t}+c\left(\tau+T_{t}\right)-\theta \log \left(\frac{T_{0}}{T_{0}-T_{t}}\right)
\end{aligned}
$$

\footnotetext{
${ }^{4}$ The model developed herein is based on Werneck (1995). See also Pires and Bugarin (2003) and Meneguin and Bugarin (2001) for other extensions of Werneck (1995).

${ }^{5}$ This implies that it is impossible (infinite cost) to collect the entire tax base $T_{0}$.
} 


\subsubsection{The state's problem}

First, consider the state's decision regarding debt accumulation and tax effort of when there is no debt renegotiation. Then, the state solves the following program, where parameter $\delta \in(0,1)$ corresponds to the intertemporal discount factor.

$$
\left\{\begin{array}{l}
\max _{\left\{D_{t}\right\},\left\{T_{t}\right\}} \sum_{t \geq 1} \delta^{t-1} U\left(D_{t}, T_{t}\right)=\sum_{t \geq 1} \delta^{t-1}\left[D_{t}+\tau+T_{t}-r\left(D_{t}, \frac{\tau+T_{t}}{B_{t}}\right) B_{t}-\psi\left(T_{t}\right)\right] \\
\text { subject to: } B_{0} \text { given } \\
\quad B_{t}=D_{t}+B_{t-1}
\end{array}\right.
$$

Note that the objective function is concave. Plugging in the restriction that characterizes debt accumulation over time into the objective function, the firstorder conditions for variables $D_{t}$ and $T_{t}$ yield the following equations.

$$
\begin{aligned}
& \frac{\partial r}{\partial D}\left(D_{t}, \frac{\tau+T_{t}}{D_{t}+B_{t-1}}\right)\left(D_{t}+B_{t-1}\right)-\frac{\partial r}{\partial \frac{\tau+T}{B}}\left(D_{t}, \frac{\tau+T_{t}}{D_{t}+B_{t-1}}\right) \frac{\tau+T_{t}}{D_{t}+B_{t-1}} \\
& +r\left(D_{t}, \frac{\tau+T_{t}}{D_{t}+B_{t-1}}\right)=1 \\
& \psi^{\prime}\left(T_{t}\right)=1-\frac{\partial r}{\partial \frac{\tau+T}{B}}\left(D_{t}, \frac{\tau+T_{t}}{D_{t}+B_{t-1}}\right)
\end{aligned}
$$

Conditions (1) and (2) clearly express the trade-offs faced by the state during the decision-making process. Expression (1) shows that the optimal deficit level equalizes the marginal cost of the debt stock (term on the right, one) with the loss associated with the marginal increase in interest rate $r$ brought about by the deficit $D_{t}$ (term on the left). Note that a deficit increase affects the financing cost for the state in three different ways. Firstly, through the marginal increase in the interest rate due to the direct deficit increase (first term); secondly, through the marginal increase in interests due to the reduction of debt sustainability (second term, which is positive despite the negative sign), and finally, through the payment of interests on the additional unit of deficit (third term).

Expression (2) shows that the optimal level of tax revenue equalizes the marginal cost of the tax effort (term on the left) with the marginal gain from the increase in expenditure (term on the right). Observe that there are two dimensions for this gain; firstly, an increase of one real in tax revenue allows expenditure of one extra real; secondly, the increase implies greater debt sustainability, which results in a marginal reduction of interests on the debt stock. ${ }^{6}$

\footnotetext{
${ }^{6}$ Since $r$ is strictly decreasing in its second variable, the term on the right in (2) is larger than one.
} 
The present model's parameterization yields the following values for variables $T_{t}^{A}, D_{t}^{A}, B_{t}^{A}, G_{t}^{A}$ and $U_{t}^{A}$ where the exponent $A$ indicates the solution of the state program before debt renegotiation. They are expressed in terms of the state variable $B_{t-1}^{A}$ at $t$.

$$
\begin{gathered}
T_{t}^{A}=T_{0}-\frac{\theta}{1+c} \\
D_{t}^{A}=\frac{1}{2}\left[\frac{1-r_{U}}{b}-B_{t-1}^{A}\right] \\
B_{t}^{A}=\frac{1}{2}\left[\frac{1-r_{U}}{b}+B_{t-1}^{A}\right] \\
G_{t}^{A}=\frac{b}{4}\left[\frac{1-r_{U}}{b}-B_{t-1}^{A}\right]^{2}-r_{U} B_{t-1}^{A}+(1+c)\left(\tau+T_{0}\right)-\theta \\
U_{t}^{A}=\frac{b}{4}\left[\frac{1-r_{U}}{b}-B_{t-1}^{A}\right]^{2}-r_{U} B_{t-1}^{A}+(1+c)\left(\tau+T_{0}\right)-\theta\left(1+\log \frac{(1+c) T_{0}}{\theta}\right)
\end{gathered}
$$

Alternatively, $T_{t}^{A}, D_{t}^{A}, B_{t}^{A}, G_{t}^{A}$ and $U_{t}^{A}$ can be rewritten as functions of the state variable at $t=1$, the initial debt stock $B_{0}$.

$$
\begin{gathered}
T_{t}^{A}=T_{0}-\frac{\theta}{1+c} \\
D_{t}^{A}=\frac{1}{2^{t}}\left[\frac{1-r_{U}}{b}-B_{0}\right] \\
B_{t}^{A}=\frac{1}{2^{t}}\left[\left(2^{t}-1\right) \frac{1-r_{U}}{b}+B_{0}\right] \\
G_{t}^{A}=\frac{b}{2^{2 t}}\left(\frac{1-r_{U}}{b}-B_{0}\right)^{2}+\frac{r_{U}}{2^{t-1}}\left(\frac{1-r_{U}}{b}+B_{0}\right)-\frac{r_{U}\left(1-r_{U}\right)}{b} \\
+(1+c)\left(\tau+T_{0}\right)-\theta \\
U_{t}^{A}=\frac{b}{2^{2 t}}\left(\frac{1-r_{U}}{b}-B_{0}\right)^{2}+\frac{r_{U}}{2^{t-1}}\left(\frac{1-r_{U}}{b}+B_{0}\right)-\frac{r_{U}\left(1-r_{U}\right)}{b} \\
+(1+c)\left(\tau+T_{0}\right)-\theta\left(1+\log \frac{(1+c) T_{0}}{\theta}\right)
\end{gathered}
$$

\subsubsection{Convergence dynamics}

Expressions $\left(3^{\prime}\right)$ through $\left(7^{\prime}\right)$ highlight some important properties related to the dynamic behavior of taxation, deficit, debt stock, expenditure, and utility of the state. 


\section{Limits}

All sequences are convergent, but the tax revenue sequence converges instantly. The limits are given by the following expressions.

$$
\begin{gathered}
T^{A}=\lim _{t \rightarrow+\infty} T_{t}^{A}=T_{0}-\frac{\theta}{1+c} \\
D^{A}=\lim _{t \rightarrow+\infty} D_{t}^{A}=0 \\
B^{A}=\lim _{t \rightarrow+\infty} B_{t}^{A}=\frac{1-r_{U}}{b} \\
G^{A}=\lim _{t \rightarrow+\infty} G_{t}^{A}=(1+c)\left(\tau+T_{0}\right)-\frac{r_{U}\left(1-r_{U}\right)}{b}-\theta \\
U^{A}=\lim _{t \rightarrow+\infty} U_{t}^{A}=(1+c)\left(\tau+T_{0}\right)-\frac{r_{U}\left(1-r_{U}\right)}{b}-\theta\left(1+\log \frac{(1+c) T_{0}}{\theta}\right)
\end{gathered}
$$

Therefore, when there is no renegotiation of the state government debt, market discipline is active in controlling fiscal policy. In the long run, the deficit tends to disappear and the debt stock and level of expenditure become stable, and so does the utility of the state. This is due to the fact that interests increase as the deficit increases and as the sustainability of the state government debt decreases, in such a way that the government optimally chooses a convergent path for the debt. However, one should emphasize that these limits depend on the hypothesis that the government cannot renege on its debt.

\section{Deficit}

The deficit convergence process depends crucially: on the initial debt stock, $B_{0}$; on its relationship with the interest rate $\left(r_{U}\right)$ established by the federal government; and on the factor that determines the sensitivity of the interest rate spread of the state to the deficit $(b)$.

Indeed, when $B_{0}<\frac{1-r_{U}}{b}$, then the initial debt stock is relatively small and the deficit sequence $\left\{D_{t}^{A}\right\}$ is positive and decreasing. In other words, the state starts off with a positive deficit and this deficit decreases with time, approaching zero asymptotically. This is the case in which the fiscal situation of the state is comfortable, with lower debt in the initial period.

On the other hand, when $B_{0}>\frac{1-r_{U}}{b}$, then the initial debt stock is too high and the deficit sequence $\left\{D_{t}^{A}\right\}$ is negative and increasing. In other words, the state chooses a high fiscal surplus, reducing it asymptotically to zero. This is the case in which the fiscal situation of the state is so bad in the initial period that it will have to strictly control its expenditures, leaving no space for deficit. 


\section{Debt}

The public debt convergence process, as occurs with the deficit, depends on the relationship between $B_{0}$ and $\frac{1-r_{U}}{b}$. If $B_{0}<\frac{1-r_{U}}{b}$, then the debt stock increases monotonically towards its limit. This is a favorable situation in which the initial debt stock is low. On the other hand, if $B_{0}>\frac{1-r_{U}}{b}$ then the initial debt is already too high and its stock decreases monotonically towards its limit.

Figures 1 and 2 present the paths of the debt and deficit/surplus for these two possible situations.

\section{Public expenditure and utility of the state}

The sequences of public expenditure and utility of the state are both strictly decreasing towards their respective limits. Note that this dynamic behavior of public expenditures is not dependent upon the behavior of the deficit and of the debt stock which, as stated above, can both increase and decrease over time, according to the parameters of the economy. The public expenditures behavior owes to the fact that the debt and deficit sequences increase in opposite directions. Optimal deficit is increasing exactly when the debt stock is decreasing. Conversely, when the debt stock is increasing, deficit decreases. The aggregate effect of the optimal choices of these two sequences is a gradual reduction in expenditures and in the utility of the state.

\subsubsection{Comparative statics}

Equations $\left(3^{\prime}\right)$ through $\left(6^{\prime}\right)$ can be used to derive comparative statics properties of the equilibrium an economy with market discipline converges to.

\section{Deficit}

The first and foremost result is that the deficit convergence point, $D^{A}$, is always zero. Therefore, when the disciplinary effect of the market works, state decisions converge to zero deficit, regardless of the values of the specific economic parameters.

\section{Tax revenue}

Tax effort, $T^{A}$, increases as the tax base increases, naturally, but also as market sensitivity to state debt sustainability, represented by parameter $c$, increases. Thus, the greater the sustainability effect on the interests paid by the state, the greater the incentive for tax collection. This is an important aspect of the disciplinary effect of the market on the state's tax policy.

Moreover, tax effort is negatively affected by administrative and by the political cost of tax collection, both represented by parameter $\theta$. The higher that parameter, the lower the tax effort of the subnational government. 


\section{Public debt}

Public debt equilibrium level, $B^{A}$, is negatively affected by the benchmark interest rate the federal government pays on its debt, $r_{U}$, and by the market sensitivity to state deficit, $b$. Thus, the more sensitive the market is to state deficit and the higher the basic interest rate is, the lower the debt stock will be in the long run.

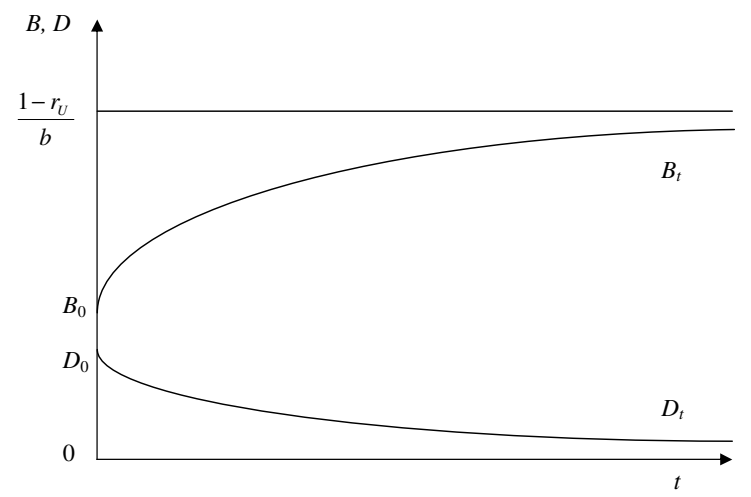

Figure 1

Time path of debt stock $B_{t}$ and the state deficit $D_{t}$ when the initial debt stock is low

\section{Public expenditure}

Public expenditure in the long run, $G^{A}$, will be higher, the higher the federal transfers, the tax base of the state, and the market sensitivity to debt sustainability, c. The latter result owes to the fact that a greater sensitivity of the interest rate causes the state to increase its tax collection in order to benefit from the consequent reduction in the interest rate on the entire debt stock, thus generating more opportunities for expenditure.

On the other hand, the higher the tax effort cost, $\theta$, and the greater the market sensitivity to the state deficit, the lower the expenditure in the long run.

Finally, one should note the nonlinear behavior of interests charged by the federal government, $r_{U}$, on the value of public expenditure in the long run. In the most natural case in which $r_{U}$ is below $50 \%$, an increase in $r_{U}$ implies a reduction in $G^{A}$. When the federal fiscal policy is less well controlled, such that $r_{U}$ is higher than $50 \%$, then an increase in $\mathrm{r}_{U}$ implies an increase in the expenditure limit $G^{A}$. 


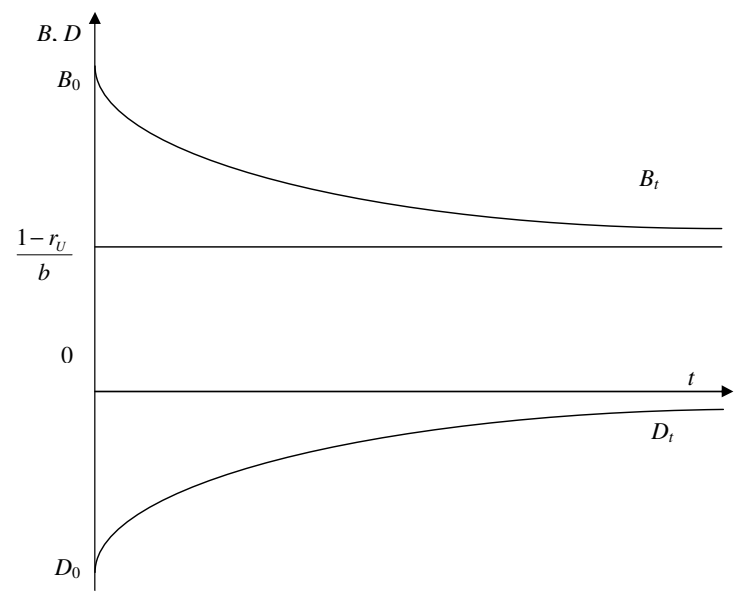

Figure 2

Time path of debt stock $B_{t}$ and the state deficit $D_{t}$ when the initial debt stock is high

\subsection{Debt renegotiation}

\subsubsection{State debt bailout}

In this simple debt renegotiation model, the federal government accepts to bail out state debt if the state accepts not to generate new deficits and to repay the federal government, based on a reduced interest rate $\bar{r}$. Therefore, the state is granted a benefit: a reduction in its debt refinancing cost. However, there is an additional sacrifice: not using the market to sustain deficits. ${ }^{7}$

If the state accepts the renegotiation contract, it is not allowed to borrow from the financial market. Furthermore, it commits itself to paying the remaining debt to the federal government at the lower interest rates $\bar{r}, \bar{r} B$. If the state refuses to pay that amount, the contract establishes that the federal government can withhold constitutional transfers from the State Participation Fund, so as to guarantee that the contract is fulfilled. On the other hand, the state still controls taxation policy without interference from the federal government. The next section analyzes the new state government problem when it accepts to renegotiate its debt.

${ }^{7}$ The contracts signed during the latest state and municipal debt renegotiation rounds were actually a lot more complex. In addition to blocking new state debt, the contracts also required primary surplus, gradual reduction of the debt-to-revenue ratio, and other more technical conditions. The current model simplifies the contract clauses by forbidding new deficits. 


\subsubsection{The new problem of the state and the incentive for debt rene- gotiation}

Suppose that the state renegotiates its debt with the federal government at time $s$. Then, the problem of the state after this renegotiation is the following:

$$
\left\{\begin{aligned}
\max _{\left\{D_{t}\right\},\left\{T_{t}\right\}} \sum_{t \geq s} \delta^{t-1} U\left(D_{t}, T_{t}\right)=\sum_{t \geq s} \delta^{t-1}\left[\tau+T_{t}-\bar{r} B_{t}-\psi\left(T_{t}\right)\right] \\
\text { subject to: } B_{s-1} \text { given } \\
B_{t}=B_{s-1}, \quad \forall t \geq s
\end{aligned}\right.
$$

The problem above introduces the characteristics of the new environment in which the state must take its decisions: zero deficit $\left(D_{t}=0\right)$ and fixed interest rates $\left(r_{t}=\bar{r}\right)$. The restriction guarantees that the state is able to roll over the debt stock with the federal government in each period, thus keeping this stock stable over time. The subscript $s-1$ used in the problem above refers to the fact that after negotiating the debt at time s the state does not issue new debt starting that period, so that $D_{s}=0$ and $B_{s}=D_{s}+B_{s-1}=B_{s-1}$. One should note that the actual renegotiation contracts are stricter, calling for gradual reduction of the debt to revenue ratio over time, until this ratio reaches an appropriate level. Therefore, the model outlined herein is favorable to states since it only requires that debt stock be frozen after the renegotiation.

Given the stationary property of the problem, its solution follows from solving at each $t \geq \mathrm{s}$ the same static maximization program below.

$$
\max _{T_{t}} U\left(T_{t}\right)=\tau+T_{t}-\bar{r} B_{s-1}-\psi\left(T_{t}\right)
$$

It is again a concave programming problem whose first-order condition yields the following expression, for each $t \geq \mathrm{s}$.

$$
\psi^{\prime}\left(T_{t}\right)=1
$$

Comparing (8) with the expression corresponding to the pre-renegotiation situation (2) clearly shows the new incentives the state is faced up with. Indeed, since $\psi$ is strictly convex, and the term on the right, larger than one in (2), was reduced to one (on the right in (8)), then tax effort will be reduced. Thus, if $T_{R}$ denotes state tax revenue after renegotiation, then $T_{R}<T^{A}$. This result is due to the fact that by offering the state a fixed interest rate $\bar{r}$ for the payment of its debt, the federal government removed one of the factors that encouraged tax effort, namely, the effect of larger tax collections on the variable interest rate $r$. Therefore, the state will have reduced incentive to raise funds from local taxes. This is an undesired but expected effect of state debt bailouts.

The present model's parameterization yields the values for variables $T_{R}, G_{R}$ and $U_{R}$ below, where subscript $R$ is the solution to the state program after debt 
renegotiation and $B_{s-1}=B_{s-1}^{A}$ is the state's debt stock at the renegotiation period.

$$
\begin{gathered}
T_{R}=T_{0}-\theta \\
G_{R}=\tau+T_{0}-\theta-\bar{r} B_{s-1} \\
U_{R}=\tau+T_{0}-\theta\left[1+\log \left(\frac{T_{0}}{\theta}\right)\right]-\bar{r} B_{s-1}
\end{gathered}
$$

Now consider the state's decision regarding the debt renegotiation scheme offered by the federal government at time $s$. Recall that if the state does not accept to renegotiate its debt, its utility will decrease in each period. Therefore, a sufficient condition ${ }^{8}$ for the state to accept the proposed scheme is that its utility at time $s$ is larger after debt renegotiation. Expression (7) describes the state's utility at time $t=s$ if the state refuses the scheme.

$$
U_{s}^{A}=\frac{b}{4}\left[\frac{1-r_{U}}{b}-B_{s-1}^{A}\right]^{2}-r_{U} B_{s-1}^{A}+(1+c)\left(\tau+T_{0}\right)-\theta\left(1+\log \frac{(1+c) T_{0}}{\theta}\right)
$$

Expressions (11) and (7) show that the utility after renegotiation will be greater than the utility without renegotiation when the condition below is fulfilled.

$$
\bar{r} \leq r_{U}-\left[c\left(\tau+T_{0}\right)-\theta \log (1+c)+\frac{b}{4}\left(\frac{1-r_{U}}{b}-B_{s}^{A}\right)^{2}\right] \frac{1}{B_{s-1}^{A}}
$$

Let $\Delta r=\left[c\left(\tau+T_{0}\right)-\theta \log (1+c)+\frac{b}{4}\left(\frac{1-r_{U}}{b}-B_{s}^{A}\right)^{2}\right] \frac{1}{B_{s-1}^{A}}$. If the federal government proposes an interest rate $\bar{r}=r_{U}-\Delta r$, then the state will accept the renegotiation contract.

If $\Delta r<0$, then the federal government can bring the renegotiation with the state to an end without any additional cost, since it will charge a higher interest rate from the subnational state than that which it will have to pay to the private sector for the new federalized debt.

On the other hand, if $\Delta r>0$, then in order to encourage the state to accept the conditions established by the contract, the federal government might have to defray the costs of offering financing at a lower interest rate than that to which its own debt is subjected.

Note that the less efficient the state is in terms of its fiscal policies (high $\theta$ ), the lower its tax base (low $T_{0}$ ), the smaller the transfers from the federal government, and the larger its debt stock, the lower the value of $\Delta r$, and consequently, the

\footnotetext{
${ }^{8}$ In fact, the necessary and sufficient condition for the state to accept the renegotiation is $\sum_{t>s} \delta^{t-s} U_{R} \geq \sum_{t \geq s} \delta^{t-s} U_{t}^{A}$. Here, the sufficient condition was used for simplicity. The author thanks an anonymous referee for drawing attention to this condition.
} 
lower its debt renegotiation cost. Therefore, the present model suggests that the negotiated interest rate should vary according to the characteristics of each state, as has apparently occurred in the latest negotiations after the Real Plan.

This article takes for granted that the federal government is willing to make the state renegotiate its debt. The rationale behind it is outside the scope of the present model; however, at least one argument, albeit external to the model, is necessary in order to support this hypothesis.

Consider the recent Brazilian history. When the Real Plan was implemented, in 1993, Brazil adopted the exchange rate control system as a way to keep tabs on inflation. That system, however, only holds if there is equilibrium in the government's external accounts. Due to the financial crises that assailed developing economies in the 1990s, the Brazilian government decided for extremely high real interest rates so as to prevent capital outflow, which could jeopardize the exchange rate control system.

Such strategy corresponds to a high increase in the basic interest rate, $r_{U}$ in the present model. Such increase calls for an important adjustment of public state finances, resulting in loss of utility, as may be checked by taking derivatives of (6) and (7) with respect to $r_{U}$. This loss of utility, on the other hand, yields naturally a lot of pressure for the federal government to propose alternative mechanisms to hold back the increase in interest rates it caused. So, the initiative of the federal government to offer a debt renegotiation contract can be seen as a response of the government to the pressures from the states for correcting a friction produced by the federal macroeconomic policy. ${ }^{9}$

The second part of the present study begins after the state has signed the debt renegotiation contract. According to the previous analysis, the state will choose a smaller tax effort than before the renegotiation, which is enough to pay its debt with the federal government ${ }^{10}$ and to maintain a level of utility (weakly) higher than that which could have been obtained had the contract not been signed.

The elected state governor obviously remains in office for a determined period of time, and therefore, after regular elections, a new governor, with his or her own election campaign, will take over. The subsequent section is concerned with how elections can affect the new governor's decision to fulfill the contract signed by his/her predecessor.

\footnotetext{
${ }^{9} \mathrm{~A}$ second and simple argument consists in observing that if the federal government enjoys stronger fiscal credibility than the state, then it can self-finance at lower interest rates. Thus, a Pareto improvement would justify the federalization of the state debt.

${ }^{10}$ This is an additional hypothesis of the model, without which the state debt renegotiation would not occur.
} 


\section{Elections and the New State Governor}

\subsection{Election platform}

Suppose now that, after debt renegotiation, statewide and nationwide elections take place. During the election campaign different candidates for the state government present the population their political platforms, which they are supposed to implement, if elected. These platforms typically correspond to projects that involve costs for the state, such as a rise in civil servants' wages, larger expenditures with education, health, public safety, etc.

Let $G_{V}$ be the total amount of resources necessary to implement the elected governor's platform. Then, the new governor should have a budget that is compatible with that expenditure. The state's budget constraint, however, is given by (10), which can be rewritten as the expression below, where subscript $s$ was removed from variable $B$ and, for simplicity, one assume that $\bar{r}=r_{U}$.

$$
G_{R}+r_{U} B=\tau+T_{0}-\theta
$$

Comparing the primary surplus (right hand side of 13) with the expenditures that are necessary to implement the platform $G_{V}$ yields two possibilities.

First, it is possible that $G_{V} \leq \tau+T_{0}-\theta-r_{U} B$. In this case, by choosing the optimal tax effort, the new governor is able to implement his/her election platform and, at the same time, comply with the previously signed renegotiation contract, paying $r_{U} B$ to the federal government.

On the other hand implementing the election platform may call for an amount of resources $G_{V}>\tau+T_{0}-\theta-r_{U} B$. In this case, the state cannot implement an optimal tax effort level $T_{R}$, pay the debt interests to the federal government, and fulfill the election promises, all at once. This second situation is investigated in more detail next.

\subsection{Election platform and debt payment}

Suppose that implementing the election platform demands for an amount of resources $G_{V}$ such that:

(i) $G_{V}>\tau+T_{0}-\theta-r_{U} B$

(ii) $G_{V}<\tau+T_{0}-\theta$

(iii) $G_{V}<\tau+T_{0}-r_{U} B$

Condition (i) implies that, as previously seen, if the new governor chooses an optimal tax effort level $\left(T_{R}\right)$ then he/she will not be able to simultaneously fulfill the election campaign promises and the renegotiation contract. Condition (ii) guarantees that, if he/she opts not to pay the federal government, the governor will 
be able to implement the election platform. ${ }^{11}$ Finally, condition (iii) guarantees that the state has a sufficiently large tax base so as to allow the new governor to fulfill the contract and his/her election promises as well, by choosing an appropriate tax effort $T_{V}>T_{R}$.

Let us analyze the incentives that the new governor will have for increasing tax revenue. The new level of tax effort is $T_{V}=G_{V}+r_{U} B-\tau<T_{0}$. The effort cost and the corresponding utility are presented below.

$$
\begin{gathered}
T_{V}=G_{V}+r_{U} B-\tau<T_{0} \\
\psi_{V}=\psi\left(T_{V}\right)=\theta \log \left(\frac{T_{0}}{\tau+T_{0}-G_{V}-r_{U} B}\right) \\
U_{V}=G_{V}-\theta \log \left(\frac{T_{0}}{\tau+T_{0}-G_{V}-r_{U} B}\right)
\end{gathered}
$$

Equations (15) and (16) again shows the relationship between the "type" of state and its utility: the higher $\theta$ is, the costlier the additional tax effort for the state, and consequently, the smaller its utility, which may prompt it to seek alternative ways to implement the political platform without additional tax burden. But what are the alternatives?

To maintain the optimal tax effort $\left(T_{R}\right)$, the state government has two options: either to neglect the election campaign promises, or to stop paying the debt interests to the federal government. Let us analyze the consequences of these two options.

If the new governor does not implement his/her election platform, he/she will solve the problem analyzed in 2.2.2 and the resulting utility will be $U_{R}$. However, the politician will become less popular among his/her voters, which will translate into a loss of utility, modeled here by parameter $d>0$. Thus, the resulting utility will be $U_{R}-d$.

If the state does not pay the amount $r_{U} B$ to the federal government, the renegotiation contract establishes that the latter may guarantee such payment by withholding the State Participation Fund transfers or even getting the corresponding payment directly from the state bank accounts. In this case, the new governor will not be able to implement the election platform, as there will not be enough resources left to do so.

Nevertheless, there exists a political cost for the federal government. On the one hand, the federal government may lose political support at the Chamber of Deputies and at the Senate, since the governor usually maintains great influence over Congress representatives from his/her state. On the other hand, the governor may turn the public opinion within the state against the federal government by arguing that the mandatory payment of debts led to unfulfilling the election

${ }^{11}$ I would like to thank an anonymous referee for drawing my attention to this condition. 
platform. Let $\lambda>0$ be this political cost for the federal government. Then, when the governor decides to stop paying the debt interests, the federal government will have to make either one of the following decisions: if it sticks to the contractual guarantees, it will bear the political cost $\lambda$ and if it acquiesces to the state's payment default, it will endure the fiscal $\operatorname{cost} r_{U} B$. The federal government's decision will depend on the relative magnitudes of each one of these variables.

As to the state, if the federal government decides to accept the default, the governor will have the highest possible utility: he/she will be able to fulfill the election campaign promises while choosing an optimal tax effort and being exempt from the payment of debt interests. The resulting utility will be $U_{R}+\mathrm{r}_{U} B$. On the other hand, if the federal government decides to apply the contractual guarantees, then the governor will not fulfill the election campaign promises, bearing a popularity cost; however, part of the popularity cost will be bailed out, since the governor will blame the federal government for withholding federal transfers. Therefore, the new cost of popularity will be $p<d$ and the resulting utility will be $U_{R}-p>U_{R}-d$.

The previous discussion suggests analyzing the strategic conflict between the state and the federal government after elections by means of the game theoretic model presented next.

\section{Post-Election Negotiation with Complete Information}

\subsection{The game between a state and the federal government}

Consider the situation analyzed in 3.2 where the new state governor $(S)$ should choose a suboptimal tax effort to fulfill election campaign promises and pay the state debt interests. Then, the decision of the state may be either to collect higher taxes $T_{V}$ (strategy $a$ ) or to keep tax effort $T_{R}$. If the governor decides to keep tax effort $T_{R}$, he/she can give up the election promises (strategy $n a$ ), suffering the corresponding political costs, or cancel the payment of debt interests (strategy $s$ ). If the governor defaults, the president $(P)$ should decide whether to apply the contractual guarantees by withholding federal transfers to that state (strategy $e$ ), or to acquiesce to the payment default, thus avoiding the cost of political confrontation with that state (strategy ne). The extensive form of the game, with its respective consequences, is shown next.

The game will be solved in the subsequent section. 


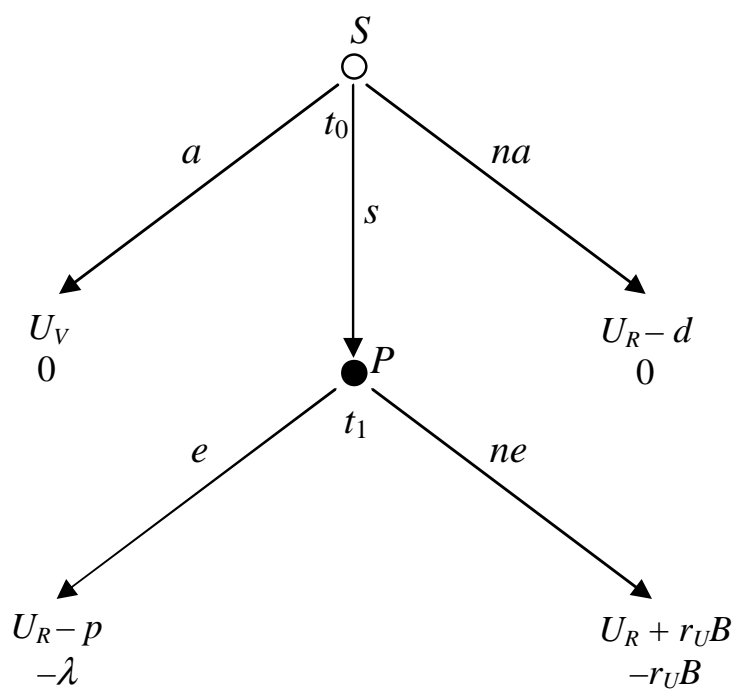

Figure 3

Game between a state and the federal

\subsection{Subgame perfect equilibria}

The complete information game is solved by backward induction, first determining the optimal decision of the federal government at node $t_{1}$ and then finding the optimal choice of the state at $t_{0}$, given the future choice of $U$. Consider three political scenarios, according to the game parameters.

Scenario 1: $\lambda<r_{U} B$ and $U_{V}>U_{R}-p$.

In this case, the political cost for the federal government to enforce the contract $(\lambda)$ is lower than the revenue loss $r_{U} \mathrm{~B}$. Thus, at $t_{1}$ the federal government will withhold federal transfers to a state defaulting on its debt $(e)$.

In turn, the state anticipates that the federal government will withhold federal transfers and given its high popularity loss from not fulfilling the election campaign promises, decides to increase tax collection at $t_{0}$, implements the election platform, and pays the debt interests $(a)$.

The resulting equilibrium is $(a, e)$, and the corresponding payoffs are $U_{V}$ and 0 for the state and for the federal government, respectively.

Scenario 2: $\lambda<r_{U} B$ and $U_{V}<U_{R}-p$.

In this case, once again, the political cost for the federal government to enforce the contract $(\lambda)$ is lower than the revenue loss $r_{U} B$. Thus, at $t_{1}$, the federal government will withhold federal transfers to the state that defaults on its debt 
payments $(e)$.

Nonetheless, the state has a very high cost in increasing the tax collection so that the governor decides to quit paying the debt interests, even though he/she understands the federal government will withhold transfers to the state and the election campaign platform will not be implemented. The cost of increasing the tax effort, along with the possibility to turn part of the public opinion against the federal government - which reduces the political cost of missing the election platform - leads the governor to confronting the federal government $(s)$.

The resulting equilibrium is $(s, e)$, and the corresponding payoffs are $\mathrm{U}_{R}-p$ and $-\lambda$ for the state and federal government, respectively.

Scenario 3: $\lambda>\mathrm{r}_{U} B$.

In this case, the political cost for the federal government to enforce the contract $(\lambda)$ is higher than the revenue loss $\left(\mathrm{r}_{U} \mathrm{~B}\right)$. Therefore, the federal government will choose not to apply contractual guarantees at $t_{1}(n e)$.

By anticipating the behavior of the federal government, the state will decide not to deviate from optimal tax effort and will default on its debt payment $(s)$ at $t_{0}$.

The resulting equilibrium is $(s, n e)$ and the corresponding payoffs are $U_{R}+r_{U} B$ for the state and $-\mathrm{r}_{U} B$ for the federal government.

\subsection{The political scenario}

The previous section showed that there are three possible equilibria for the complete information game between the state and the federal government. Which equilibrium will actually be played will depend on the political scenario the state and the federal government are facing. Scenarios 1 and 2 correspond to situations in which the federal government is politically strong, and is then able to confront the state. These are situations in which the value of parameter $\lambda$ is relatively low. Such cases are more common at the beginning of a presidential tenure when a new president has won the elections with a landslide majority, thus having a lot of political capital.

In scenario 1 , the cost of tax effort is low for the governor. Therefore, knowing that the federal government is ready to withhold transfers, the state governor will increase tax collection. This is a naturally desirable equilibrium, since public finances do not deteriorate and politicians fulfill the promises made to their constituents.

In scenario 2 , the high cost of tax effort leads the state to default on its debt payments. This situation is undesirable because it implies a political cost both for the state and for the federal government, but it is inevitable due to the "inefficient" type of state $(\theta)$.

Political scenario 3, on the other hand, depicts a situation in which confrontation with the state represents a large political cost for the federal government, and 
therefore, it will try to avoid it despite the fiscal cost involved in such a choice. Such situation is more likely to happen when the new president is given a poor popularity rating for having won a very close election race, or in the case of a re-election when society expects no real novelty in the government. Note that, in this case, the state defaults on its debt payments even when $U_{V}>U_{R}-$ p, i.e., when it would be willing to make an additional tax effort if nonpayment resulted in losing federal transfers. ${ }^{12}$ This is clearly an extremely undesirable situation for the federal government, which faces worsening of its fiscal accounts. Moreover, the debt renegotiation contract becomes absolutely void.

The next section shows that under the latter scenario, the consequences of state debt renegotiation are even more dramatic when all involved states are brought into consideration.

\subsection{Many states and the "debt renegotiation paradox"}

Consider political scenario 3 , characterized by political fragility of the federal government, and now include not only one state, but all the $\mathrm{n}$ states that renegotiated their debts. The corresponding dynamic game takes on the following form. In a first period (period 1), state $S_{1}$ decides whether or not to pay the debt interests to the federal government and, if it does not, the federal government decides whether or not to withhold federal transfers to this state (the game built in 4.1, between state $S_{1}$ and the federal government). After the federal government's decision, period 2 begins, in which state $S_{2}$ decides whether or not to pay the debt interests to the federal government and, if it does not, the federal government decides again whether or not to withhold federal transfers to this state (a new round of the game built in 4.1, now with state $\mathrm{S}_{2}$ and the federal government). This relationship continues likewise up to the last period $(n)$ where the last state $S_{n}$ decides about paying its debt interests and the federal government reacts by withholding or not federal transfers to this state. The game then ends.

The game is solved by backward induction. In the last period $(n)$, due to its political fragility, the federal government decides not to withhold federal transfers to state $S_{n}$, if it does not pay its debt interests. State $S_{n}$ anticipates that behavior and decides to default. The argument above is repeated in periods $n-1, n-2$, etc. up to the first period, where $S_{1}$ defaults and is not punished by the federal government. In the only subgame perfect equilibrium found in this case, the federal government will receive payment from no state, regardless of its financial health, resulting in a revenue loss of $r_{U}\left(B_{1}+\ldots+B_{n}\right)$ where $B_{i}$ corresponds to the debt stock of state $S_{i}, i=1, \ldots, n$, which was federalized during the state debt renegotiation process.

A similar result was derived in Selten (1978) in the context of industrial orga-

\footnotetext{
${ }^{12}$ But still, the state would decide not to pay the debt interests even if $G_{V} \leq t+T_{0}-\theta-r_{U} B$, i.e., when the state can simultaneously fulfill its election promises and pay the debt without deviating from an optimal tax effort.
} 
nization. ${ }^{13}$ By analogy, one could refer to the phenomenon observed in the present model as the "debt renegotiation paradox": although state debt renegotiation is a complex process, resulting in an extremely detailed contract, such contract is not credible, since the states will not pay back their debts and the political fragility of the federal government will not allow it to enforce the contract.

In that case, it should be highlighted that state debt renegotiation is worse for the country than the previously existing situation. In fact, on the one hand, before renegotiation, market discipline generated more incentives for tax effort of the states, as previously discussed $\left(T^{A}>T_{R}\right)$. On the other hand, contracts have an additional cost to the federal government, which bails out state debts without any financial return from these subnational governments.

Despite this first extremely negative result, the next section argues that the hypothesis of complete information should be modified so as to obtain a more realistic model, from which a more interesting equilibrium may derive.

\section{Incomplete Information, Experimentation and Reputation}

\subsection{Different types for the state and the federal government}

Consider again the game shown in figure 1 . If the state has complete information about the political cost of confrontation for the federal government, then one of the previously analyzed equilibria will be played. In particular, if the federal government is weak (very high $\lambda$ ), then the state will default on its debt payments. However, the hypothesis that the value of $\lambda$ is public knowledge is very strong. In fact, a new government is also taking over at the federal level and it is quite difficult to know how the new president will react to a political confrontation with the state. In the present section we assume that the value of $\lambda$ is private information of the federal government and that the state has incomplete information about this parameter, which may have two different values.

A weak federal government is one that has a high $\lambda^{w}$ value for the political cost $\lambda$, such that:

$$
\lambda^{w}>r_{U} B
$$

On the other hand, a strong federal government is one that has a low $\lambda^{S}$ value for the political cost $\lambda$, such that:

\footnotetext{
${ }^{13}$ The model presented by Selten describes a chain formed by $n$ stores, each of them being a local monopoly in a different city. In each city, there is a potential entrant. If this entrant enters, the monopolist should decide whether to engage in a price war that is detrimental to both or to accommodate, sharing the market, now duopolistic, with the entrant. The solution to the game implies that the monopolist will peacefully accept the entry of the new entrant in all $n$ cities, generating a remarkable profit reduction to the chain-store. Selten referred to this phenomenon as the "chain-store paradox".
} 


$$
\lambda^{S}<r_{U} B
$$

Although the federal government knows its type, the state only knows that this type is $\lambda^{S}$ with probability $\mu$, and $\lambda^{w}$ with probability $1-\mu$. Note that a weak federal government, denoted here by $P^{w}$ ( $P$ : president), prefers to acquiesce to the nonpayment of debt interests by the state, whereas a strong federal government, denoted here by $P^{S}$, will automatically withhold federal transfers to the defaulting state.

By analogy, the federal government also has incomplete information about the state, which may be either strong or weak. A state is regarded as strong $\left(\mathrm{S}^{S}\right)$ when the political cost of confrontation with the federal government, $p^{S}$, is reduced, such that:

$$
U_{V}<U_{R}-p^{S}
$$

On the other hand, a state is regarded as weak $\left(\mathrm{S}^{w}\right)$ when the political cost of confrontation with the federal government, $\mathrm{p}^{w}$, is high, such that:

$$
U_{V}>U_{R}-p^{w}
$$

Thus, a strong state is willing to grapple with the federal government, deciding not to pay its debt interests even if it knows that the federal government will withhold federal transfers. On the other hand, a weak state prefers to increase its tax effort in case the federal government withholds its transfers. The federal government does not observe the type of state, knowing only that it is strong with probability $\nu$, and weak with probability $1-\nu$. Next section builds and solves the incomplete information game between a state and the federal government.

\subsection{The incomplete information game between a state and the federal government}

Figure 4 describes the incomplete information where there are two possible types for the state and two possible types for the federal government. Note that strategy na was not included in the extensive form game, due to the fact that na is always strictly dominated by strategy s, regardless of the type of state and of the federal government's decision (recall $p<d$ ).

As this is an incomplete information game, one look for its perfect Bayesian equilibria. The solution to this game is quite simple since there are dominant strategies for three out of four types of agents involved. Indeed, a strong federal government will always withhold federal transfers to a defaulting state. Instead, a weak federal government will acquiesce to the state's nonpayment of debt interests. On the other hand, a strong state defaults regardless of the type of federal government. It remains to determine what a weak state will do. 


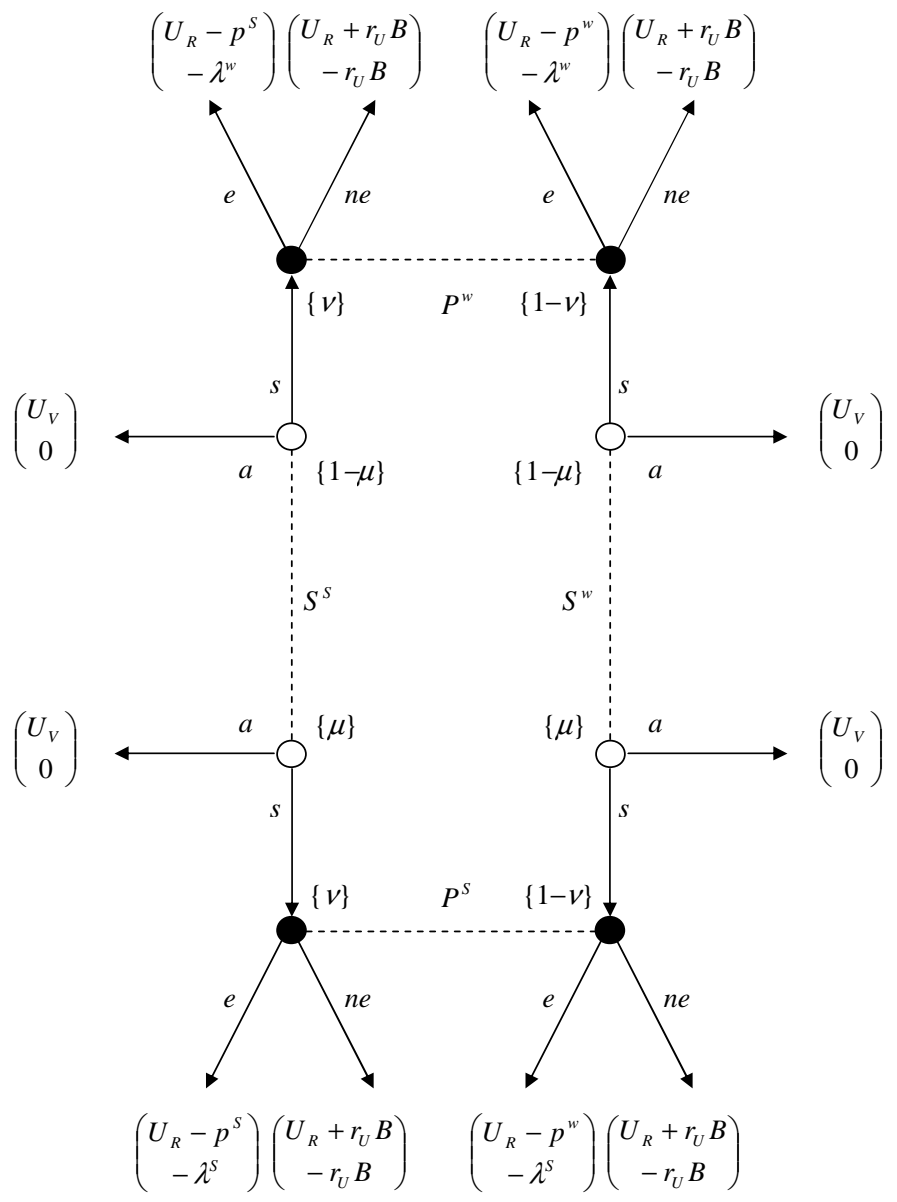

Figure 4

Incomplete information game between a state and the federal government 
A weak state $S^{w}$ has two options: $a$ and $s$. Its expected utilities for each of these strategies, given the dominant strategies of the federal government, are the following.

$$
\begin{gathered}
E U\left(S^{w} \mid a\right)=U_{V} \\
E U\left(S^{w} \mid s\right)=\mu\left(U_{R}-p^{w}\right)+(1-\mu)\left(U_{R}+r_{U} B\right)=U_{R}+(1-\mu) r_{U} B-\mu p^{w}
\end{gathered}
$$

Note that, if $\mu=0$, then $E U\left(S^{w} \mid s\right)=U_{R}+r_{U} B>U_{V}$. On the other hand, for $\mu=1$, we have $E U\left(S^{w} \mid s\right)=U_{R}-p^{w}<U_{V}$. Thus, $\mathrm{S}^{w}$ will choose a if $\mu$ is sufficiently high and will choose s otherwise. More precisely, let $\mu_{0}=\frac{U_{R}+r_{U} B-U_{V}}{r_{U} B+p^{w}} \in$ $(0,1)$. Then:

(i) If $\mu>\mu_{0}, \mathrm{~S}^{w}$ will choose strategy $a$.

(ii) If $\mu<\mu_{0}, \mathrm{~S}^{w}$ will choose strategy $s$.

Next we analyze each one of these cases.

\subsubsection{The experimentation principle}

Suppose that $\mu<\mu_{0}$. Then $\mathrm{S}^{w}$ will choose s, i.e., the state will not pay its debts regardless of its type. In that situation, the governor believes that the new president is politically weak with high probability. Hence, if the federal government is actually weak, the state will have a high return. On the other hand, if the federal government is strong, it will withhold federal transfers in order to pay for the state's debt interests. One can interpret the observed equilibrium as an experimentation-type equilibrium: the state believes the president is politically weak with high probability, and tests his/her reaction to defaulting. In that case, the equilibrium will reveal the type of federal government, since a strong federal government will withhold federal transfers to the state, whereas a weak federal government will necessarily acquiesce to the nonpayment of the debt.

The corresponding equilibrium is not uncommon in situations in which there is a shift of power and the new ruler is tested by the existing political forces. The cases of the state government of Minas Gerais in early 1999 and of Rio de Janeiro in early 2003, mentioned in the introduction, are examples of this type of equilibrium.

\subsubsection{The precautionary principle}

Suppose now that $\mu>\mu_{0}$. Then $\mathrm{S}^{w}$ will choose $a$, so that only the strong state will default. The weak state will strive, in an additional tax effort, to simultaneously pay the debt interests and fulfill its election platform. The weak state believes that it is dealing with a strong federal government with high probability and therefore it acts with caution, avoiding a likely detrimental confrontation. 
Note that, in this case, the type of federal government will only be known if the state is actually strong, as a weak state does not force the federal government to take any decision that might reveal its type.

Also observe that the ex-ante belief $\mu$ of the state regarding the type of federal government is favorable to the latter, regardless of its type. In fact, this belief makes the weak state avoid defaulting, which is the best possible equilibrium for the federal government. The next section analyzes how a weak federal government can benefit from this favorable belief in a dynamic model involving more than one state, so as to avoid the debt renegotiation paradox described in 4.4.

\subsection{Sustaining reputation}

Suppose now that the federal government plays a dynamic incomplete information game involving two states and two periods. In the first period, state 1 makes its decision concerning debt interests payment and the federal government decides about withholding federal transfers to this state if it defaults. In the second period, state 2 observes the result of the interaction between state 1 and the federal government and decides about debt interests payment. The federal government reacts to the decision made by state 2 and the game ends.

This strategic relationship can be seen as two "copies" of the game shown in figure 4 . In the first copy, the federal government interacts with state 1 whereas in the second one it does so with state 2 . The "copies" are sequentially played and each state derives its utility in a different period. The federal government, however, derives its utility in every period. For simplicity, let the sum of utilities of the federal government in each period be its utility in the game, disregarding any intertemporal discount factor.

Also suppose that $\mu>\mu_{0}$ as in 5.2 .2 , i.e., the states believe that the federal government is strong with high probability, suggesting a cautious behavior of the state in the first period.

The important distinction between this sequential game and two independent applications of the stage game lies in the updating of beliefs about the type of federal government in the second period. Indeed, if, in the first period, a weak federal government meets a strong state, then by acquiescing, it completely reveals its type. Then, in the second period, the belief that state 2 must be dealing with a strong federal government is updated from $\mu$ to $\mu_{2}=0$. Therefore, state 2 knows it is dealing with a weak federal government and will then default on its payment, regardless of its type.

Thus, when repeating the one-period dominant strategy a weak federal government may reveal its type in the first period, which, in turn, may result in an unfavorable behavior of the state in the second period. In that case, the federal government's reputation, which was initially favorable with $\mu>\mu_{0}$, is lost at the end of the first period.

In other words, the revealed information can destroy the benefits to the federal 
government of the state's cautious behavior observed in the previous section. The following analysis seeks to determine the perfect Bayesian equilibrium of this more complex game. To do so, we add the following hypothesis.

$$
\nu<2-\frac{\lambda^{w}}{r_{U} B}
$$

The expression above affirms that, although the political cost of confrontation with the state is high for a weak federal government $\left(\lambda^{w}>r_{U} B\right)$, the probability of dealing with a strong state $(\nu)$ is sufficiently low. Note that in order for this condition to be met, the political cost $\lambda^{w}$ should not be extremely high: $\lambda^{w}<$ $2 r_{U} B$. As we shall see, this hypothesis will make it in the best interest of a weak federal government to act as a strong one in order to influence the behavior of a weak state in the second period.

In order to solve the game, note that a strong state has a dominant strategy, namely defaulting. Moreover, the dominant strategy of a strong federal government is to withhold federal transfers to any defaulting state in any of the two periods. The dominant strategy of a weak federal government in the second period consists in acquiescing to the nonpayment of state debt. Furthermore, in the first period, according to the analysis made in the previous section, a weak state will not declare a moratorium. Finally, the decision of a weak state in the second period depends on its beliefs $\mu_{2}$ updated using Bayes' rule: if $\mu_{2}<\mu_{0}, \mathrm{~S}^{w}$ will choose s and if $\mu_{2}>\mu_{0}, S^{w}$ will choose $a$.

Now, one should determine the optimal strategy of a weak federal government in the first period, noting that this decision may affect the beliefs of the weak state in the second period. A weak federal government has two alternatives when dealing with a defaulting state (therefore, necessarily a strong state) in the first period. If it acquiesces, it will naturally reveal its type; but in the subsequent period, the state will update its beliefs to $\mu_{2}=0$ and will default. On the other hand, if it decides to withhold federal transfers to state 1 , it will have a high political cost, but it will not reveal its type. In this case, in the second period, a weak state will keep its original belief $\mu_{2}=\mu$ and will pay the debt interests. The expected utilities from a weak federal government for each of the possible strategies, in case of default in period 1 , are described below.

$$
\begin{gathered}
E U\left(P^{w} \mid e\right)=-\lambda^{w}-\nu r_{U} B-(1-\nu) 0 \\
E U\left(P^{w} \mid n e\right)=-r_{U} B-\nu r_{U} B-(1-\nu) r_{U} B
\end{gathered}
$$

The first term on the right hand side of the above expressions corresponds to the utility received in the first period, whereas the two subsequent terms calculate the expected utility in the second period.

Hypothesis (23) yields $E U\left(P^{w} \mid e\right)>E U\left(P^{w} \mid n e\right)$. Thus, in the only perfect Bayesian equilibrium of this game, a weak federal government withholds federal 
transfers to a defaulting state, in spite of the important political cost in the first period, in order to prevent a weak state from defaulting in the second period.

This equilibrium requires a costly procedure for the weak federal government to maintain its reputation. Its policy suggestion is clear: the federal government should punish any defaulting state in the first period, in order to prevent the debt renegotiation program from falling apart, due to the difficulties elected state governors may face when trying to fulfill their election campaign commitments.

However, this equilibrium will only hold if the federal government has somehow already built a favorable reputation in the first place, so that the states believe it is strong with high probability: $\mu>\mu_{0}$. What can one say about the equilibrium in the case $\mu<\mu_{0}$, i.e., when, in the first period, the states estimate that the federal government is weak with high probability? The next section shows that, even in such case, the federal government has a strategic opportunity for building a favorable reputation in the future.

\subsection{Reputation building}

Suppose that $\mu<\mu_{0}$. Then, as previously shown, the state will choose to default in the first period, regardless of whether it is weak or strong. Also, as previously observed, the dominant strategy of a strong federal government consists in withholding federal transfers to the defaulting state. What will the weak federal government make in this situation?

If the weak federal government also decides to withhold federal transfers in the first period, then there will be no information revealed in equilibrium. Therefore, there will be no Bayesian updating and the beliefs in the second period, $\mu_{2}$, will remain $\mu_{2}=\mu<\mu_{0}$. But then, the state will default in the second period, too. However, this cannot be a Nash equilibrium, since a weak federal government would rather not have withheld federal transfers in period 1.

Therefore, the same toughening behavior found when the state believed the federal government was strong with high probability is no longer optimal now that the state believes the federal government is likely weak.

On the other hand, if the federal government keeps its optimal strategy in the single-period game, i.e., to withhold federal transfers if it is strong and not to do so if it is weak, then the equilibrium is totally revealing at the end of the first period. Thus, at the beginning of the second period, the state knows exactly if it is dealing with a weak or strong federal government. Therefore, a weak state will not default in the second period after observing that the federal government withheld federal transfers in the first period. But then, as seen in the previous section, a weak federal government would be better off disguising itself as strong, holding federal transfers to the defaulting state in the first period, in order to make a weak state behave properly in the second period. This argument shows that there is no pure strategies equilibrium when $\mu<\mu_{0}$.

The following theorem shows that there is always a perfect Bayesian equilib- 
rium in mixed strategies for this game. Proof details are presented in the Appendix.

Theorem 1 Consider the two-period game between two states and the federal government. Suppose that:

- The ex-ante probability of the federal government being strong is $\mu<\mu_{0}$;

- Condition (23) holds: $\nu<2-\frac{\lambda^{f}}{r_{U} B}$.

Then, there is a perfect Bayesian equilibrium in mixed strategies for each value of $\mu$, as described next:

(a) Suppose that $\mu>\mu_{0}^{2}$.

In the first period, a strong state will default on its debt payment whereas a weak state will pay its debt. A strong federal government will withhold federal transfers to any defaulting state. Finally, a weak federal government will withhold federal transfers to a defaulting state with probability $\theta=\frac{\mu}{1-\mu} \frac{1-\mu_{0}}{\mu_{0}}$.

In the second period, a strong state will not pay its debt. A weak state will default on its debt payment with probability $\pi_{2}=\frac{1}{1-\nu}\left[2-\nu-\frac{\lambda^{f}}{r_{U} B}\right]$ and will pay its debt with probability $1-\pi_{2}$. A strong federal government will withhold federal transfers to any defaulting state. Finally, a weak federal government will not withhold federal transfers to a defaulting state.

(b) Suppose that $\mu=\mu_{0}^{2}$.

In the first period, a strong state will quit paying its debt. A weak state will default with probability $\pi_{1} \in[0,1]$ and will pay it with probability $1-\pi_{1}$. A strong federal government will hold federal transfers to any defaulting state. Finally, a weak federal government will hold federal transfers to a defaulting state with probability $\theta=\frac{\mu_{0}}{1+\mu_{0}}$.

In the second period, a strong state will not pay its debt. A weak state will default with probability $\pi_{2}=\frac{1}{1-\nu}\left[2-\nu-\frac{\lambda^{f}}{r_{U} B}\right]$ and will pay its debt with probability $1-\pi_{2}$. A strong federal government will withhold federal transfers to any defaulting state. Finally, a weak federal government will not withhold federal transfers to a defaulting state.

(c) Suppose that $\mu<\mu_{0}^{2}$.

In the first period, the state will not pay its debt, regardless of its type. A strong federal government will withhold federal transfers to any defaulting state. Finally, a weak federal government will withhold federal transfers to a defaulting state with probability $\theta=\frac{\mu}{1-\mu} \frac{1-\mu_{0}}{\mu_{0}}$.

In the second period, a strong state will not pay its debt. A weak state will default with probability $\pi_{2}=\frac{1}{1-\nu}\left[2-\nu-\frac{\lambda^{f}}{r_{U} B}\right]$ and will pay its debt with probability $1-\pi_{2}$. A strong federal government will withhold federal transfers to any defaulting state. Finally, a weak federal government will not withhold federal transfers to a 
defaulting state.

Even though states believe that the federal government is weak with high probability, a weak federal government can build a reputation of strength by means of its strategy in the first period. In the first case, where $\mu>\mu_{0}^{2}$, the federal government manages to induce a weak state to pay its debt in the first period and, in the second period, it manages to partially control this weak state. In the second case, where $\mu=\mu_{0}^{2}$, the federal government partially controls the weak state in both periods. Finally, in the third case, in which beliefs are too unfavorable to the federal government $\left(\mu<\mu_{0}^{2}\right)$, it is not able to control the weak state in the first period, but can partially control it in the second period.

In any case, reputation is partially built, with partial control of the weak state in the second period. However, the building of this reputation is costly for a weak federal government, which has to confront a defaulting state with positive probability.

The main novelty in the situation in which the federal government does not yet have a reputation $\left(\mu<\mu_{0}\right)$ is the optimality of a mixed strategy by the weak federal government in the first period. In fact, the previous strategy of always withholding federal transfers is costly and does not allow the updating of beliefs in equilibrium, so that a weak state in the second period continues to be encouraged to default. Therefore, extreme rigidity, which was optimal when the federal government already had a strong reputation, is a suboptimal strategy when the federal government has yet to build a reputation.

\section{Extensions}

The basic model described in 5.3 can be successfully extended in several ways, as discussed next for the case in which $\mu>\mu_{0}$.

\subsection{Intertemporal discount factor}

Including an intertemporal discount factor $\delta$ in the utility of the federal government makes the benefit obtained in the second period in the reputation equilibrium less important to the federal government. However, if a weak federal government does not overly discount the future, it will still be optimal to withhold federal transfers to a defaulting state in the first period. To be more precise, the condition that guarantees the reputation equilibrium changes from condition (23) to the following condition.

$$
\lambda^{w}-r_{U} B<\delta(1-\nu) r_{U} B
$$

Provided that condition (24) is satisfied, a weak federal government will continue to withhold federal transfers to a defaulting state in the first period. 


\subsection{More than two states}

Although there are over two dozen Brazilian states and even though several municipalities have renegotiated their debts with the federal government, the game presented in 5.3 allows for only two states. However, the argument generalizes naturally to $\mathrm{n}$ states, using backward induction. In the game before the last one (with state $n-1$ ), a weak federal government that did not reveal its type in any of the previous periods will decide to punish a defaulting state provided that condition (24) is satisfied. Consider now the period before. If the weak federal government punishes a defaulting state, it induces the weak state to pay its debt in the following period $(n-1)$ and still maintains its type unrevealed, which will also be advantageous in the last period. Thus, the federal government will be even more prompted to withhold federal transfers to a strong defaulting state, and condition (24) is more than enough to guarantee this behavior by a weak federal government. This clearly occurs up to the first period.

Therefore, the same condition that guarantees a reputation equilibrium in the model with two states, also guarantees it when there are $\mathrm{n}$ states.

The extensions described above show that the model is robust to an intertemporal discount factor and a higher number of states involved. Other extensions are less immediate and are discussed as suggestions for further research.

\subsection{Heterogeneous states}

An implicit hypothesis in the analysis in 5.3 is that the states are identical in terms of their debts with the federal government, and in terms of their political cost. In fact, this is a simplifying and clearly unrealistic hypothesis. The model can be extended to include heterogeneity among the different states. State $\mathrm{S}_{i}$ renegotiated debt $\mathrm{B}_{i}$ and is able to inflict political cost $\lambda_{i}$ in a confrontation with the federal government. In addition, the federal government estimates that state $i$ is strong with probability $\nu_{i}$.

The model extends immediately to this change if the definition of a strong or weak federal government is not modified. In this case, a sufficient condition for a reputation equilibrium is:

$$
\lambda_{i}^{w}-r_{U} B_{i}<\delta\left(1-\nu_{i}\right) r_{U} B_{i}, \quad i=1, \ldots, n
$$

The difficulty in this case lies in the fact that the definition of a strong or weak federal government also depends on variable parameters $\lambda_{i}$ and $B_{i}$ (see conditions (17) and (18)). Thus, the same federal government can be weak in the confrontation with one state and strong in the confrontation with another one, which may result in a partial revelation of the type of the federal government when it acquiesces to a very strong state. A more detailed study of the different circumstances in case of heterogeneity among states may yield new and interesting results. 


\subsection{Simultaneous game}

The framework presented in this paper requires a very particular order in the negotiation process between the federal government and the states, after the elections: first a state, then a second one, a third, etc. Actually, one may imagine situations in which several states default at the same time.

In this case, the game must be modified in order to keep its dynamic characteristic. A natural way to introduce this extension is to suppose that all states in each period decide simultaneously and independently about paying their debt. In other words, the states start off playing a simultaneous (static) game among them. After observing the number of states that decided to default on their debts, the federal government decides to punish or not these states. Then, there is a second period in which each state decides again - and simultaneously between states to default or not on its debt, followed by the federal government's reaction. The game may have a finite or infinite horizon.

In a model in which the states are homogeneous or in which there is reduced heterogeneity, the federal government will find it optimal to withhold federal transfers to each defaulting state, given the future reputation benefit. In fact, the federal government will have higher incentives to withhold transfers than in the original model. Note that this argument will be valid provided that the effect of the political cost of each confrontation on the utility of the federal government takes on the additive form. However, it seems reasonable to suppose that there is an externality on the cost of one more simultaneous confrontation for the federal government. If that is the case, it is quite possible that there may be an equilibrium in which all states default considering that the cost for a weak federal government confronting them would be extremely high. Then, the game would end with the total failure of the debt renegotiation contracts. Thus, a careful analysis of a model that is both simultaneous (several states deciding at the same time whether to default or not) and dynamic (several periods) could also yield new and interesting results, including issues related to state coalition formation.

\section{Conclusion}

The recent debt renegotiation process after the implementation of the Real Plan was comprehensive - including even municipalities - , and quite complex in terms of the political negotiations. Moreover, it resulted in the federalization of a large amount of state and municipal debts, which partly explains the poor performance of the federal government regarding public debt accumulation. ${ }^{14}$ Despite the rigid contracts signed by the subnational governments, newly sworn-in governors and mayors, who get to know of the delicate fiscal situation of their respective states and municipalities only when they take over, frequently complain about the

\footnotetext{
${ }^{14}$ According to Villela (2002), debt renegotiations of states and municipalities has accounted for one third of the increase in the federal government's debt since 1994.
} 
required payment of debt interests to the Brazilian Treasury Department.

This situation has already led some Brazilian states, such as Minas Gerais and Rio de Janeiro, to stop debt payments, forcing the Treasury Department to apply contractual guarantees, withholding federal transfers to defaulting states.

The aim of this study was to assess two moments in this negotiation process between states (and municipalities) and the federal government by using contract theory and game theory. First, a stylized model for debt renegotiation highlighted the situations that may lead a state to renegotiate its debt, in spite of the contract requirement forbidding new debt, at least for some time. Among the effects of renegotiation, the model demonstrated the reduced incentive for states to generate local tax revenue.

The second moment occurs after renegotiation of state debts and after elections, when new governors take over, bringing along their election campaign promises. The corresponding equilibria first suggested a generalized tendency towards a moratorium on state debt, the so-called "debt renegotiation paradox".

Nevertheless, when states have incomplete information about the federal government's willingness to withhold federal transfers in case of default, then two equilibria can be identified. In the first one, which we call experimentation equilibrium, the state believes that the federal government will have little strength to cope with the political cost of withholding federal transfers. In this case, the state decides not to pay its debt, although it understands that if the federal government decides to withhold federal transfers, the political cost for the state will be extremely high. In this equilibrium, if the federal government does not withhold transfers to a defaulting state, then all players learn it is weak. Therefore, the other states will also default on their debt payments.

A second equilibrium, which we call reputation equilibrium, is obtained when the state believes that there is a high probability that the federal government is willing to withhold federal transfers. In this case, only a state in a too unfavorable fiscal situation will decide not to pay its debt. Then, the federal government will be willing to cope with the political cost of holding federal transfers, even if this involves a high cost, so as to prevent other states from defaulting on the payment of their debts in the future.

In the latter equilibrium, the federal government accepts the political cost today in order to have a fiscal benefit tomorrow, which will guarantee the survival of the debt renegotiation contracts, whose costs have already been transferred to the federal government once too often.

Finally, the optimal strategy of the federal government becomes more complex in a situation in which the federal government does not have a well-established reputation. In this case, the states believe that the federal government is weak with high probability and, therefore, it is not optimal for the federal government to always withhold federal transfers to defaulting states. However, by adopting a mixed strategy, a weak federal government may manage to build the reputation 
of being tough, which will be rewarded in the subsequent periods.

The policy recommendation of the present paper is quite clear. The federal government should not acquiesce to the nonpayment of debt; otherwise, the contracts will be nothing but symbolic documents that will be ignored by the subnational governments, bringing about a large impact on federal public finance. If the federal government has a strong reputation, then its optimal strategy will be to withhold federal transfers to any defaulting state. If its reputation is not well established yet, it is still possible to construct a favorable reputation by withholding federal transfers to a defaulting state. However, in the latter case, the decision to withhold federal transfers is made with probability lower than one, i.e., there will not always be federal transfer blocking in equilibrium.

The basic ideas of the paper have a more general application and usually suit other situations, among which the Brazilian Fiscal Responsibility Law is the most important. Indeed, compliance with this law should be carefully checked by the federal government and the punishments in case of noncompliance must be harsh and immediate. This may be, in fact, the best, and perhaps the only way, the federal government can sustain its reputation, guaranteeing that the law will not disintegrate over time.

\section{References}

Bevilaqua, A. S. (2000). State-government bailouts in Brazil. Discussion paper 421, Department of Economics, PUC-Rio.

Kreps, D. \& Wilson, R. (1982). Reputation and imperfect information. Journal of Economic Theory, 27:253-79.

Meneguin, F. B. \& Bugarin, M. S. (2001). Reeleição e política fiscal: Um estudo dos efeitos da reeleição nos gastos públicos. Economia Aplicada, 5(3):600-622.

Milgrom, P. \& Roberts, J. (1982). Predation, reputation and entry deterrence. Journal of Economic Theory, 27:280-312.

Pires, H. A. A. \& Bugarin, M. S. (2003). Metas de déficit: Transferências intergovernamentais e o controle do endividamento dos estados. Revista Brasileira de Economia, 54(4):775-94.

Pires, H. A. A. \& Bugarin, S. (2002). A credibilidade da política fiscal: Um modelo de reputação para a execução das garantias fiscais pela União junto aos Estados após o programa de ajuste fiscal e a lei de responsabilidade fiscal. In Finanças Públicas: VI Prêmio Tesouro Nacional, pages 215-250. ESAF, Brasília.

Selten, R. (1978). The chain store paradox. Theory and Decision, 9:127-159.

Sotomayor, M. A. \& Bugarin, M. S. (1998). Lições de teoria dos jogos. Manuscrito. 
Versiani, F. R. (2003). A dívida pública interna e sua trajetória recente. Texto para Discussão 284, Departamento de Economia, UnB.

Villela, R. (2002). Motivos para não refinanciar. Folha de São Paulo.

Werneck, R. L. F. (1995). Federalismo fiscal e a política de estabilização no Brasil. Revista Brasileira de Economia, 49(2):375-390. 


\section{Appendix}

\section{Proof of the Theorem}

The discussion that precedes the statement of the theorem clearly establishes that:

(i) A strong state will default on the payment of its debt in any period.

(ii) A strong federal government will withhold federal transfers to a defaulting state in any period.

(iii) A weak federal government will not withhold federal transfers to a state in the second period.

(iv) There is no perfect Bayesian equilibrium in which a weak federal government adopts a pure strategy in the first period in case of default by a state.

Suppose that a weak federal government decides to withhold federal transfers to a defaulting state with probability $\theta \in(0,1)$ in the first period. Consider the decision of a weak defaulting state in the first period. Its corresponding expected utilities are:

$$
\begin{gathered}
E U\left(S^{w} \mid a\right)=U_{V} \\
E U\left(S^{w} \mid s\right)=[\mu+(1-\mu) \theta]\left(U_{R}-p^{w}\right)+(1-\mu)(1-\theta)\left(U_{R}+r_{U} B\right)
\end{gathered}
$$

The previous expressions yield:

$$
\begin{gathered}
E U\left(S^{w} \mid a\right) \\
E U\left(S^{w} \mid s\right) \Leftrightarrow \theta<\frac{\mu_{0}-\mu}{1-\mu}
\end{gathered}
$$

Consider three possible cases for the comparative size of $\theta$ and $\frac{\mu_{0}-\mu}{1-\mu}$.

Case 1: $\theta>\frac{\mu_{0}-\mu}{1-\mu}$.

In this case, a weak state will adjust $(a)$ and will not default on the debt payment in period 1 . Two distinct situations may occur in period 2 , depending on what occurred in period 1 , as analyzed next.

Situation 1: There was default of payment in period 1 and the weak federal government did not withhold federal transfers to the defaulting state.

This situation occurs with probability $1-\theta$ in equilibrium. Then the weak federal government reveals its type, there will be generalized payment default in the second period, and the utility of $P^{w}$ will be $-2 \mathrm{r}_{U} B$. 
Situation 2: There was default of payment in period 1 and the weak federal government withheld federal transfers to the defaulting state.

This situation occurs with probability $\theta$. In this case, in the second period $S^{w}$ will update its beliefs about dealing with a strong federal government, according to Bayes' rule, to:

$$
\mu_{2}=\frac{\mu}{\mu+(1-\mu) \theta}
$$

Note that $\mu_{2}>\mu$. Therefore, the federal government's mixed strategy induced the state to make an upward adjustment of its beliefs about dealing with a strong federal government. One should now analyze the different situations regarding the relationship between $\mu_{2}$ and $\mu_{0}$.

If $\mu_{2}<\mu_{0}$, then $S^{w}$ will choose $s$ and there will be generalized default of payment in the second period. The utility of $P^{w}$ will be $-\lambda^{w}-\mathrm{r}_{U} B$. What happens in this case is that the upward adjustment of the weak state's belief about the federal government is too small, and the state keeps on believing that the federal government is weak with high probability, causing it to default on the payment of its debt. But then, it would have been better for the weak federal government if it had not withheld federal transfers to the state in period 1. Therefore, a perfect Bayesian equilibrium is not possible in this case.

If $\mu_{2}>\mu_{0}$, then $S^{w}$ will choose $a$ and the utility of $P^{w}$ in situation 2 will be: $-\lambda^{w}-\nu r_{U} B-(1-\nu) 0=-\lambda^{w}-\nu r_{U} B$. Therefore, the expected utility of $P^{w}$ in the game is: $\theta\left(-\lambda^{w}-\nu r_{U} B\right)+(1-\theta)\left(-2 r_{U} B\right)$. In order for this strategy to correspond to an equilibrium in mixed strategies, it is necessary that $P^{w}$ be indifferent between each of its pure strategies, or that $-\lambda^{w}-\nu r_{U} B=-2 r_{U} B$. However, this equality contradicts condition (23). Therefore, there is no perfect Bayesian equilibrium in this case either.

If $\mu_{2}=\mu_{0}$, then $S^{w}$ is indifferent between $s$ and $a$ in the second period. Suppose then that $S^{w}$ chooses $s$ with probability $\pi_{2}$ and $a$ with probability $1-\pi_{2}$. Then, the utility of $P^{w}$ in situation 2 will be: $-\lambda^{w}-\nu r_{U} B-(1-\nu)\left[\pi_{2} r_{U} B+\left(1-\pi_{2}\right) 0\right]=$ $-\lambda^{w}-\nu r_{U} B-(1-\nu) \pi_{2} r_{U} B$. Therefore, the expected utility of $P^{w}$ in the game, when there is default in the first period is: $\theta\left[-\lambda^{w}-\nu r_{U} B-(1-\nu) \pi_{2} r_{U} B\right]+$ $(1-\theta)\left(-2 r_{U} B\right)$. In order for this strategy to correspond to an equilibrium in mixed strategies, it is necessary that $P^{w}$ be indifferent between each one of its pure strategies, or that $-\lambda^{w}-\nu r_{U} B-(1-\nu) \pi_{2} r_{U} B=-2 r_{U} B$, which occurs if and only if $\pi_{2}=\frac{1}{1-\nu}\left[2-\nu-\frac{\lambda^{w}}{r_{U} B}\right] \in[0,1]$.

To conclude the equilibrium construction, note that $\mu_{2}=\mu_{0}$ is equivalent to $\theta=\frac{\mu}{1-\mu} \frac{1-\mu_{0}}{\mu_{0}}$. Finally, in order for the value of $\theta$ to satisfy the condition required in Case 1 , it is necessary that $\mu>\mu_{0}^{2}$. This is the equilibrium described in item (a) of the Theorem. 
Case 2: $\theta=\frac{\mu_{0}-\mu}{1-\mu}$.

In this case, a weak state is indifferent between strategies $a$ and $s$. Suppose then that $S^{w}$ chooses $s$ with probability $\pi_{1}$ and $a$ with probability $1-\pi_{1}$ in period 1. Then, similarly to the analysis in Case 1 , when there is default by the state (with probability $\pi_{1}$ ) and withholding of federal transfers (with probability $\pi_{1} \cdot \theta$ ), the state updates its belief in period 2 to:

$$
\mu_{2}=\frac{\mu}{\mu+(1-\mu) \theta}=\mu_{0}
$$

Therefore, the only value of $\theta$ compatible with the above expression is $\theta=$ $\frac{\mu}{1-\mu} \frac{1-\mu_{0}}{\mu_{0}}$. However, the condition $\theta=\frac{\mu_{0}-\mu}{1-\mu}$ holds only if $\mu=\mu_{0}^{2}$. Thus $\theta=\frac{\mu_{0}}{1+\mu_{0}}$, which is the equilibrium described in item $(b)$ of the Theorem.

Case 3: $\theta<\frac{\mu_{0}-\mu}{1-\mu}$.

In this case, a weak state will default on the payment of its debt in period 1 . The analysis is similar to that of Case 1. Two different situations may occur in period 2, depending on the reaction of the weak federal government in period 1 , as analyzed next.

Situation 1: The weak federal government does not withhold federal transfers to the defaulting state. This situation occurs with probability $1-\theta$ in equilibrium. Then the weak federal government reveals its type, there will be generalized default of payment in the second period, and the utility of $P^{w}$ will be $-2 r_{U} B$.

Situation 2: The weak federal government withholds federal transfers to the defaulting state.

This situation occurs with probability $\theta$. In this case, in the second period $S^{w}$ will update its beliefs about dealing with a strong federal government, according to Bayes' rule, to:

$$
\mu_{2}=\frac{\mu}{\mu+(1-\mu) \theta}
$$

Note that $\mu_{2}>\mu$. Therefore, the federal government's mixed strategy led the state to make an upward adjustment of its belief about dealing with a strong federal government. One should now assess the different situations regarding the comparison between $\mu_{2}$ and $\mu_{0}$.

If $\mu_{2}<\mu_{0}$, then $\mathrm{S}^{w}$ will choose $s$ and there will be generalized default of payment in the second period. The utility of $P^{w}$ will be $-\lambda^{w}-\mathrm{r}_{U} B$. What happens in this case is that the upward adjustment of the belief of the weak state about the federal government is too small, and the state keeps on believing that the federal government is weak with high probability, causing it to default on the payment of its debt. Then, it would have been better for the weak federal government if it 
had not withheld federal transfers to the state in period 1. Therefore, a perfect Bayesian equilibrium is not possible in this case.

If $\mu_{2}>\mu_{0}$, then $S^{w}$ will choose $a$ and the utility of $P^{w}$ in situation 2 will be: $-\lambda^{w}-\nu r_{U} B-(1-\nu) 0=-\lambda^{w}-\nu r_{U} B$. Therefore, the expected utility of $P^{w}$ in the game is: $\theta\left(-\lambda^{w}-\nu r_{U} B\right)+(1-\theta)\left(-2 r_{U} B\right)$. In order for this strategy to correspond to an equilibrium in mixed strategies, it is necessary that $P^{w}$ be indifferent between each of its pure strategies, i.e., $-\lambda^{w}-\nu r_{U} B=-2 r_{U} B$. However, this equality contradicts condition (22). Therefore, there is no perfect Bayesian equilibrium in this case either.

If $\mu_{2}=\mu_{0}$, then $S^{w}$ is indifferent between $s$ and $a$ in the second period. Suppose then that $S^{w}$ chooses $s$ with probability $\pi_{2}$ and a with probability $1-\pi_{2}$. Then, the utility of $P^{w}$ in situation 2 will be: $-\lambda^{w}-\nu r_{U} B-(1-\nu)\left[\pi_{2} r_{U} B+\left(1-\pi_{2}\right) 0\right]=$ $-\lambda^{w}-\nu r_{U} B-(1-\nu) \pi_{2} r_{U} B$. Therefore, the expected utility of $P^{w}$ in the game is: $\theta\left[-\lambda^{w}-\nu r_{U} B-(1-\nu) \pi_{2} r_{U} B\right]+(1-\theta)\left(-2 r_{U} B\right)$. In order for this strategy to be part of an equilibrium in mixed strategies, it is necessary that $P^{w}$ be indifferent between each one of its pure strategies, i.e., $-\lambda^{w}-\nu r_{U} B-(1-\nu) \pi_{2} r_{U} B=$ $-2 r_{U} B$, which occurs if and only if $\pi_{2}=\frac{1}{1-\nu}\left[1-\nu-\frac{\lambda^{f}}{r_{U} B}\right]<1$.

Finally, note that $\mu_{2}=\mu_{0}$ is equivalent to $\theta=\frac{\mu}{1-\mu} \frac{1-\mu_{0}}{\mu_{0}}$. Finally, in order for the value of $\theta$ to satisfy the condition required in Case 3 it is necessary that $\mu<\mu_{0}^{2}$. This is the equilibrium described in item $(c)$ of the Theorem. 